\title{
River water quality in weathered limestone: A case study in upper Mahanadi basin, India
}

\author{
B K PANIGRAHY ${ }^{1}$ and B C RAYMAHASHAY ${ }^{2}$ \\ ${ }^{1}$ Civil Engineering Department, Kakatiya Institute of Technology and Science, Warangal 5506015 (A.P), India. \\ ${ }^{2}$ Civil Engineering Department, Indian Institute of Technology, Kanpur 208016 (U.P), India.
}

\begin{abstract}
Stromatolitic limestone and calcareous shale belonging to Chattisgarh Supergroup of Proterozoic age dominate the upper part of the Mahanadi river basin. X-ray diffractogram (XRD) of limestone rocks show presence of a significant amount of calcite, dolomite and ankerite. Shales of various colours contain calcite and dolomite. It is observed that congruent dissolution of carbonate minerals in the Charmuria pure limestone has given rise to a typical karst topography. On the other hand, limestones are also seen to support red and black soil profiles. This indicates that the limestone bedrock undergoes a parallel incongruent weathering, which leaves a residue of decomposed rock. The XRD analyses reveal that the limestone soils thus formed contain an assemblage of quartz, clays and Fe-oxides. It is likely that the silicate component trapped during deposition of the stromatolitic limestone weathers incongruently resulting in diverse soil profiles. Carbonate and silicate mineral weathering schemes have been worked out to explain the soil formation, fixation of $\mathrm{Al}$ in clay minerals, and $\mathrm{Fe}$ in goethite. The water quality parameters such as $\mathrm{Ca}, \mathrm{Mg}$ and $\mathrm{HCO}_{3}$ in the river water suggest under saturation with respect to calcite and dolomite. The mineral stability diagrams indicate that kaolinite and Ca-smectite are stable in the river water environment, hence they occur in suspended sediments and soils. The dominant influence of carbonate weathering on the water quality is observed even in the downstream part of the river outside the limestone terrain.
\end{abstract}

\section{Introduction}

Rock weathering is a fundamental step within the fluvial erosion cycle vis-a-vis river water composition. The end product of rock-water interactions in river catchment areas is an assemblage of secondary minerals in soils and sediments. In studies involving river water quality, the transfer of solutes are expressed in terms of biomass uptake, cyclic salt precipitation, and chemical weathering of bed rocks (Drever 1997). In watersheds where human interference is negligible, chemical weathering assumes a major role in influencing water composition. Based on the environmental factors that influence river water chemistry, Gibbs (1970) suggested a three- fold classification of rivers

- low total dissolved solids (TDS) and high $\mathrm{Na} /(\mathrm{Na}+\mathrm{Ca})$ water controlled by rainfall

- intermediate TDS and low $\mathrm{Na} /(\mathrm{Na}+\mathrm{Ca})$ water controlled by rock weathering and

- high TDS and high $\mathrm{Na} /(\mathrm{Na}+\mathrm{Ca})$ water controlled by evaporation.

Berner and Berner (1987) showed that the above three groups in fact represent three types of rock weathering. The first group is controlled by nonreactive drainage basin containing cation poor siliceous soils and rocks. The second group includes most of the major rivers of the world and represents weathering of sedimentary rocks dominated

Keywords. River water quality modeling; rock-water interaction; limestone weathering; Chattisgarh basin. 


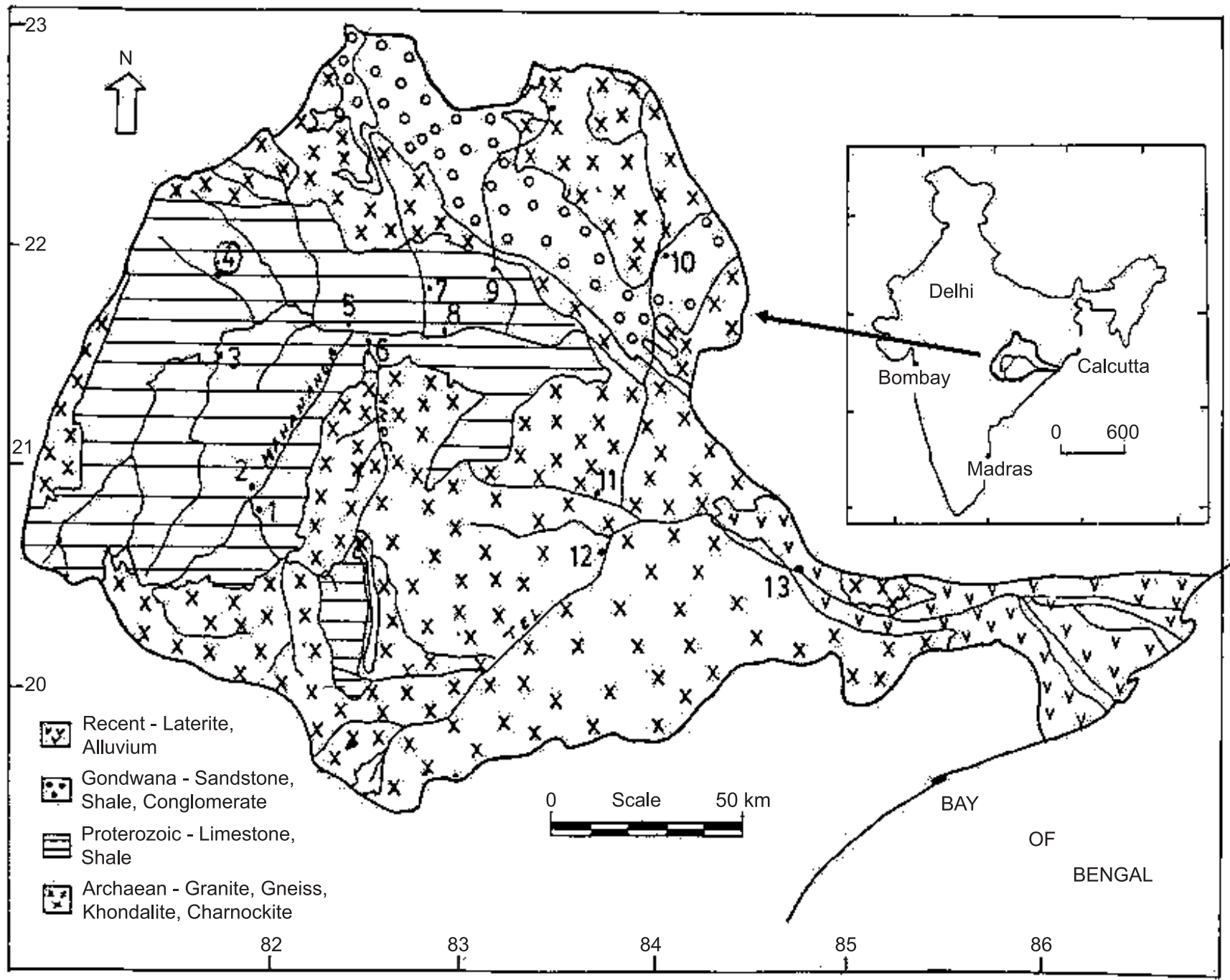

Figure 1. Geological map of the Mahanadi basin (compiled from GIS maps, 1977).

by $\mathrm{CaCO}_{3}$ component. The third group represents rivers draining evaporite beds. Stallard and Edmond (1983) established the dominant role of chemical weathering of calcareous rocks in the Amazon river basin through mass balance and solution equilibria. Meybeck (1987) in an extensive study covering a number of large watersheds in France emphasized silicate and carbonate weathering effects on water quality. Ohrui and Mitchell (1998) have demonstrated control of weathering products on water chemistry of small Japanese rivers. A comprehensive review of coupling between weathering and water quality has been provided by Berner and Berner (1987) and Drever (1988) for the world's major river basins.

A large volume of work is on record pertaining to the sediment mineralogy and river erosion in the major river basins of the Indian subcontinent. Subramanian (1987) provides a comprehensive overview of such studies. Naidu et al (1985) have described clay mineral characteristics of river bed sediments. A chemical weathering model based on bicarbonate content in river waters was suggested by Raymahashay (1986). An evaluation of the Mahanadi river water chemistry has been carried out by Chakrapani and Subramaniam (1990). Ray et al (1984) and Naidu et al (1985) have pointed out certain limitations about the nature and source of sediment mineralogy reported in earlier studies by Subramaniam and his co-workers. The limitations were mainly because of sampling stations, statistically inadequate sample size, information on the type of rocks in the basin and technique of clay mineral identification. There have been very few attempts to evaluate water quality through analysis of lithology and soil formation in the drainage basins of India. Existing literature shows that most of the works on Indian rivers are focused on generating water chemistry database with sampling stations located near the river mouth. This may be due to easy accessibility in the coastal areas. On the other hand, it is 
Table 1. Lithostratigraphy of the Chattishgarh basin (modified after Murti 1987 and Das et al 1990).

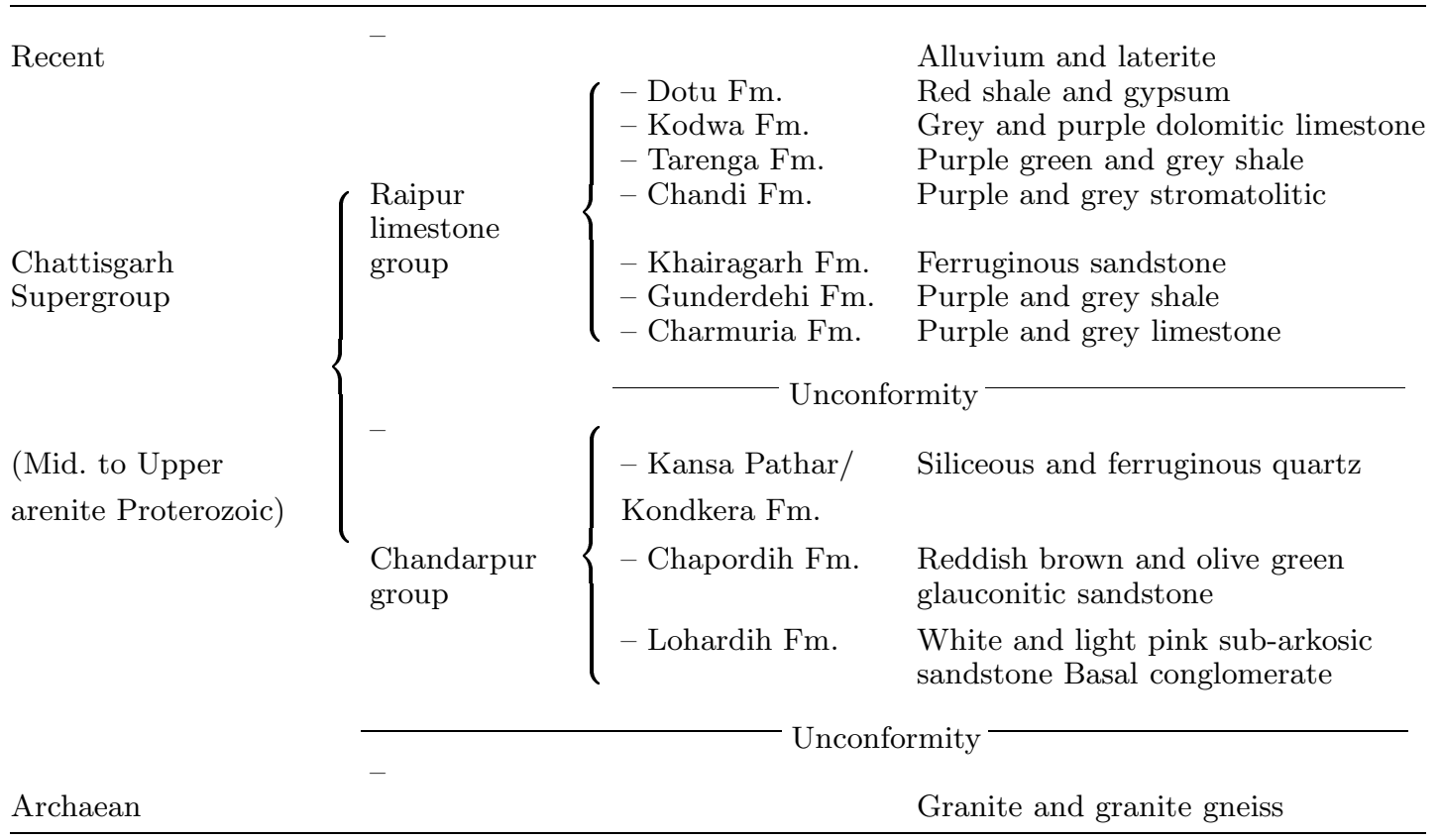

Note: Das et al (1990) identified and characterized Dotu and Kodwa Formations, overlying Tarenga Formations in the northwestern part of the basin. Murty (1987) gave the stratigraphy of the central part. This is an integrated account of lithostragraphy compiled from the above sources.

obvious that any effect of rock type on water quality will not be clearly discernible near the mouth due to human interferences. Therefore, in such studies, more attention should be focused at the portion hydrologically considered as the upstream part of the river because of its relatively pristine nature.

In the present study, the selection of the upstream part of the river comprises an area of $46,700 \mathrm{~km}^{2}$ up to the sampling station 8 (figure 1). It has the Seonath, the largest tributary, the Pairi, the Hamp, and the Mahanadi river up to Jondhra. Together, these tributary basins cover nearly one-third of the total basin area. The understanding that water quality and soil formation could be better evaluated in areas free from human interference and recent deposits prompted the choice. Extensive fieldwork and petrologic study were carried out to understand the basin geology and sediment clay mineralogy.

\section{Geology of the basin}

The Mahanadi is the second major river in peninsular India with respect to the water potential. It has a catchment area of $148,589 \mathrm{~km}^{2}$. The river originates from a pond at an elevation of $457 \mathrm{~m}$ above mean sea level near Nagri town in Madhya Pradesh of central India and debouches over $66 \mathrm{~km}^{3}$ of water (Rao 1979) into the Bay of Bengal. Major tributaries of the river are Pairi, Seonath, Jonk, Hasdo, Mand, Ib and Tel. The climate is tropical to sub-tropical with an average annual rainfall of $144 \mathrm{~cm}$. The Indian Meteorological Department has reported that the basin has a high rate of evapotranspiration varying from $152 \mathrm{~cm}$ in the east to $174 \mathrm{~cm}$ in the west.

The entire Chattisgarh basin forms the upper Mahanadi catchment area. This basin is one of the seven Purana basins in India, which are believed to have developed under a dominant extensional tectonic regime, and fed with eroded material from Archaean and Early Proterozoic continental crust of the Peninsular shield. These rock formations are the repositories of shallow marine sediments in an unmetamorphosed but marginally deformed state (Kale 1991). The Archaean group of rocks unconformably underlies the sedimentary formations of the Chattisgarh basin. Das et al (1989) and Mukherjee (1990) gave the stratigraphic sequence of the northwestern and southwestern parts of the basin respectively. An integrated account of lithostratigraphy applicable to the entire Chattisgarh Supergroup is given in table 1. Petrography and XRD analyses of the rock samples from all the formations were carried out (table 2). It is found that the area comprises mostly limestone and shale with pockets of sandstone. The limestones are generally stromatolitic and dolomitic in nature. Stromatolite columns are separated by calcareous mud and stand out prominently on weathering. XRD 
Table 2. Summary of the mineralogy of rock samples revealed by X-ray diffraction analysis and microscopic examination.

\begin{tabular}{llll}
\hline Formation & Location & Rock type & \multicolumn{1}{c}{ Mineralogy } \\
\hline Dotu & Andhiyarkore & Reddish shale & $\mathrm{Q}+\mathrm{I}+\mathrm{Chl}+\mathrm{F}+\mathrm{K}+\mathrm{H}$ \\
Kodwa & Kodwa & Grey limestone & $\mathrm{D}+\mathrm{Q}+\mathrm{C}+\mathrm{F}$ \\
& Raipura & Shaly limestone & $\mathrm{D}+\mathrm{Q}+\mathrm{I}+\mathrm{F}+\mathrm{K}+\mathrm{C}$ \\
Tarenga & Singarpur & Green shale & $\mathrm{Q}+\mathrm{F}+\mathrm{D}+\mathrm{C}+\mathrm{Chl}+\mathrm{K}$ \\
& Singarpur & Black shale & $\mathrm{Q}+\mathrm{F}+\mathrm{I}+\mathrm{D}$ \\
& Simra & Purple shale & $\mathrm{Q}+\mathrm{F}+\mathrm{Q}+\mathrm{I}+\mathrm{Chl}+\mathrm{D}$ \\
Chandi & Sonadih & Purple limestone & $\mathrm{A}+\mathrm{C}+\mathrm{Q}+\mathrm{F}+\mathrm{G}+\mathrm{K}+\mathrm{Chl}$ \\
& Lakchanpur & -do- & $\mathrm{D}+\mathrm{C}+\mathrm{Q}+\mathrm{I}+\mathrm{K}$ \\
& Dhaneli & -do- & $\mathrm{A}+\mathrm{Q}+\mathrm{I}+\mathrm{F}$ \\
& Sonbanrsa & Grey limestone & $\mathrm{D}+\mathrm{C}+\mathrm{Q}+\mathrm{I}+\mathrm{K}+\mathrm{G}$ \\
& Dhabadih & -do- & $\mathrm{D}+\mathrm{C}+\mathrm{Q}$ \\
Khairagarh & Nipania & -do- & $\mathrm{D}+\mathrm{C}+\mathrm{Q}$ \\
Gunderdehi & Binayakpur & Reddish sandstone & $\mathrm{Q}+\mathrm{H}+\mathrm{I}+\mathrm{K}$ \\
Charmuria & Khorsi Nala & Purple shale & $\mathrm{Q}+\mathrm{C}+\mathrm{F}+\mathrm{I}+\mathrm{K}+\mathrm{Chl}+\mathrm{D}$ \\
& Rajim & Grey limestone & $\mathrm{C}+\mathrm{Q}+\mathrm{I}$ \\
Chandarpur & Durg & Purple limestone & $\mathrm{C}+\mathrm{Q}+\mathrm{I}+\mathrm{F}+\mathrm{D}$ \\
& Banrodh and & Sandstone and & $\mathrm{Q}+\mathrm{F}+\mathrm{G}$ \\
Archaean & Mudpar & Quartz-arenite & \\
\hline
\end{tabular}

Q - Quartz; F - Felspar; C - Calcite; D - Dolomite; A - Ankerite; B - Biotite; I - Illite; K Kaolinite; H - Hematite; P - Pyroxene; Chl - Chlorite; G - Glauconite.

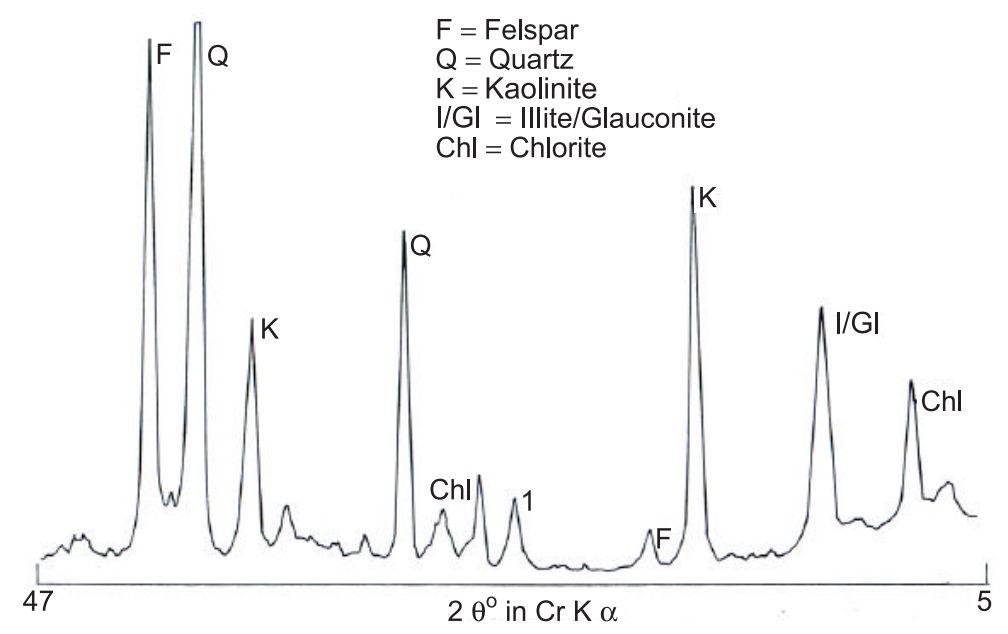

Figure 2. Sketch of X-ray diffraction pattern of $\mathrm{HCl}$ treated limestone.

analysis of a number of samples revealed that these limestones are impure. The limestones contain a significant fraction of silicate minerals such as quartz (4.266 $\AA$ ), albitic felspar (3.196 and 6.4 $\AA$ ), illite/glauconite (10.04 and $4.99 \AA)$, kaolinite (7.09 and $3.52 \AA$ ) and chlorite (14.28 and $4.72 \AA$ ), in addition to calcite, dolomite and ankerite. The XRD pattern given in figure 2 provides the mineral assemblage of acid-leached residue of a typical stromatolitic limestone. Shale formations occurring in the basin are also often calcareous with additional chlorite and kaolinite.

\section{Limestone weathering and soil formation}

It is noteworthy that the limestone bedrock supports thin soil cover at a number of places in the study area. An assemblage of solution features and bare rock surfaces in pure limestone regions, which are typical of the karst topography could be noticed. Mineralogical examination of river suspended sediment indicates the presence of unweathered felspar and occasional calcite, in addition to dominant clay minerals. Size analysis of 
Table 3. Standard state Gibbs energy of formation and equilibrium constants for stability of glauconite in the soil environment at $25^{\circ} \mathrm{C}$ and $1 \mathrm{~atm}$.

\begin{tabular}{|c|c|c|}
\hline \multicolumn{3}{|c|}{ Gibbs energy of formation of mineral and related species } \\
\hline Glauconite $^{*}$ & $(\mathrm{gl}), \quad \mathrm{K}_{1.5}\left(\mathrm{Fe}_{3.16}^{3+} \mathrm{Fe}_{0.84}^{2+}\right) \mathrm{Al}_{0.66} \mathrm{Si}_{7.34} \mathrm{O}_{20}(\mathrm{OH})_{4}$ & $:-9296.80$ \\
\hline Nontronite* & $(\mathrm{no}), \quad \mathrm{K}_{0.66}\left(\mathrm{Fe}^{3+}\right)_{4} \mathrm{Al}_{0.66} \mathrm{Si}_{7.34} \mathrm{O}_{20}(\mathrm{OH})_{4}$ & $:-9053.30$ \\
\hline Kaolinite $^{\dagger}$ & (ka), $\quad \mathrm{Al}_{4} \mathrm{Si}_{4} \mathrm{O}_{10}(\mathrm{OH})_{8}$ & $:-7598.72$ \\
\hline Goethite $^{\dagger}$ & (go), $\mathrm{FeOOH}$ & $:-488.55$ \\
\hline $\mathrm{K}^{+\dagger}$ & & $:-282.49$ \\
\hline $\mathrm{H}_{2} \mathrm{O}^{\dagger}$ & & $:-237.13$ \\
\hline $\mathrm{H}_{4} \mathrm{SiO}_{4}^{\dagger}$ & & $:-1307.74$ \\
\hline $\mathrm{H}^{+}$and $\mathrm{O}_{2}$ gas ${ }^{\dagger}$ & & :Zero \\
\hline gl-no boundary: & \multicolumn{2}{|c|}{$\begin{array}{l}\mathrm{Gl}+0.21 \mathrm{O}_{2}+0.84 \mathrm{H}^{+}=\mathrm{no}+0.84 \mathrm{~K}^{+}+0.42 \mathrm{H}_{2} \mathrm{O} \\
\log \left(\mathrm{a}_{\mathrm{K}}+\mathrm{a}_{\mathrm{H}}^{+}\right)=9.3 \text { for } P_{\mathrm{CO}_{2}}=0.21 \text { atm in earth's atmosphere }\end{array}$} \\
\hline \multicolumn{3}{|c|}{$\begin{array}{l}\text { no-ka+go boundary: } \\
\qquad \begin{array}{l}6 \mathrm{no}+4 \mathrm{H}^{+}+82 \mathrm{H}_{2} \mathrm{O}=\mathrm{ka}+24 \mathrm{go}+4 \mathrm{~K}^{+}+40 \mathrm{H}_{4} \mathrm{SiO}_{4} \\
\log \left(\mathrm{a}_{\mathrm{K}^{+}} / \mathrm{a}_{\mathrm{H}^{+}}\right)+10 \log \mathrm{aH}_{4} \mathrm{SiO}_{4}=-43.85\end{array}\end{array}$} \\
\hline$g l-k a+g o$ boundar & $\begin{array}{l}6 \mathrm{gl}+1.26 \mathrm{O}_{2}+9.04 \mathrm{H}^{+}+79.48 \mathrm{H}_{2} \mathrm{O} \\
=\mathrm{ka}+24 \mathrm{go}+9.04 \mathrm{~K}^{+}+40 \mathrm{H}_{4} \mathrm{SiO}_{4} \\
\log \left(\mathrm{a}_{\mathrm{K}^{+}} / \mathrm{a}_{\mathrm{H}^{+}}\right)+4.42 \log \mathrm{aH}_{4} \mathrm{SiO}_{4}=-8.64\end{array}$ & \\
\hline
\end{tabular}

${ }^{*}$ Calculated by the oxide summation method (Tardy and Garrels 1974).

${ }^{\dagger}$ Converted to KJ/mole following Robie et al (1978).

suspended sediments of four upland tributaries has shown that nearly $70 \%$ of the suspended load is silt. These observations are in accordance with a typical weathering limited denudation regime (Stallard and Edmond 1983), which usually has the following characteristics:

- development of thin soil profiles or bare rock surfaces,

- presence of partially weathered primary minerals in the stream load,

- availability of less time for soil and water interaction and

- imprint of rock weathering on river sediment load.

The weathering surfaces of the limestone bedrock in the Chandi formation show standard solution features like cavities, open joints, stylolites, etc. This impure limestone appears to have undergone both congruent and incongruent weathering simultaneously. This is because of its high silicate mineral content. Congruent dissolution of the carbonate minerals has resulted in typical karst features mentioned earlier. Calcite and dolomite are major carbonate minerals. Ankerite was detected in some samples by characteristic Xray peak between 2.89 and $2.90 \AA$ and an endothermic DTA peak below $800^{\circ} \mathrm{C}$. Previous reports of ground water and river water analysis from the area (Panigrahy 1991) suggest that most of the ground water as well as the Seonath river water are super-saturated with respect to a calcite and dolomite, which explains widespread occurrence of carbonate concretions in this area.

On the other hand, incongruent weathering of silicate minerals is responsible for the formation of two types of soil covers observed in the area. They are: (i) concretionary red soil (Terra Rossa) and (ii) organic rich black soil (Rendzina). Mineralogical investigation of these soils reveals that the kaolinite-illite-quartz assemblage is common to both. But the red soil is characterized by goethite concretions while the black soil contains nontronite. Such soil mineralogy may be due to the trapping of silicate minerals during deposition of the stromatolitic limestone. Energy Dispersive $\mathrm{X}$-ray Analysis (EDAX) of the residue remaining after $\mathrm{HCl}$ leaching of this rock shows the presence of glauconite, which is probably a primary source of iron for geothite formation. Composition of the glauconite agrees with the idealized glauconite given by Burst (1958). Within the soil environment, the glauconite initially alters to nontronite that in turn gives rise to an assemblage of kaolinite and goethite. Wolf (1967) suggested that spheroidal particles of goethite could be pseudomorphs of glauconite. These mineralogical changes are general characteristics of silicate weathering reactions with additional oxidation of ferrous-iron to ferric-iron. The ferric iron ultimately is fixed as goethite. Thus, conversion of such glauconite to an ideal nontronite is worked out in the following steps: 


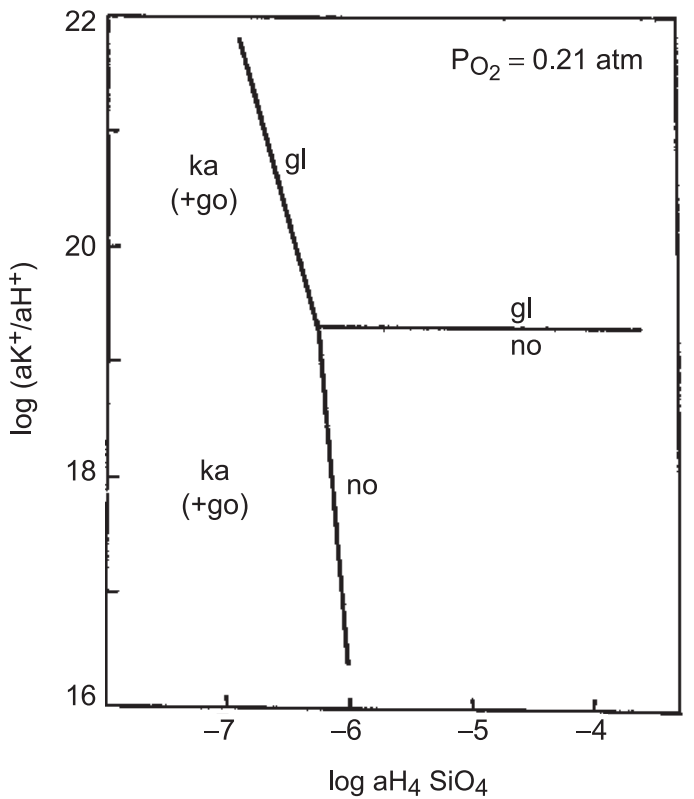

Figure 3. Stability fields of glauconite (gl), nontronite (no) and kaolinite (ka) with goethite (go) at $25^{\circ} \mathrm{C}$.

Glauconite $=\mathrm{K}_{0.66} \mathrm{Fe}_{3.16}^{3+} X+0.84 \mathrm{Fe}^{2+}+0.84 \mathrm{~K}^{+}$

$$
0.84 \mathrm{Fe}^{2+}+0.21 \mathrm{O}_{2}+0.84 \mathrm{H}^{+}=0.84 \mathrm{Fe}^{3+}
$$$$
+0.42 \mathrm{H}_{2} \mathrm{O}
$$

$\mathrm{K}_{0.66} \mathrm{Fe}_{3.16}^{3+} \mathrm{X}+0.84 \mathrm{Fe}^{3+}=$ Nontronite

Glauconite $+0.21 \mathrm{O}_{2}+0.84 \mathrm{H}^{+}$

$$
=\text { Nontronite }+0.84 \mathrm{~K}^{+}+0.42 \mathrm{H}_{2} \mathrm{O}
$$

Similarly, the weathering of nontronite to kaolinite and goethite involves release of $\mathrm{K}^{+}$ion and dissolved silica $\left(\mathrm{H}_{4} \mathrm{SiO}_{4}\right)$. The overall reactions for glauconite-nontronite, nontronite-kaolinite + goethite and glauconite-kaolinite + goethite equilibria are provided in table 3 along with respective Gibbs energy values used to calculate equilibrium constants. From these data, a stability diagram (figure 3) in terms of the thermodynamic activity of $\mathrm{K}^{+}, \mathrm{H}^{+}$and $\mathrm{H}_{4} \mathrm{SiO}_{4}$ is constructed by following the method of Garrels and Christ (1965). Even though the idealized compositions might introduce considerable uncertainty in the position of the boundaries, it is reasonable to conclude that glauconite is destabilized at relatively high $\mathrm{pH}$, high $\mathrm{K}^{+}$ion activity and low silica activity.

\subsection{Relative mobility of elements}

The proposed weathering scheme for the carbonate and silicate fractions in limestone is based on the
Table 4. Relative mobility of elements during weathering of limestone.

\begin{tabular}{cccc}
\hline Element $^{*}$ & $\begin{array}{c}\text { Average } \\
\text { limestone }\end{array}$ & Average soil & Soil/limestone \\
\hline $\mathrm{Si}$ & 8.77 & 37.80 & 4.31 \\
$\mathrm{Al}$ & 3.73 & 17.86 & 4.79 \\
$\mathrm{Fe}$ & 1.66 & 38.90 & 23.43 \\
$\mathrm{Ca}$ & 81.40 & 2.60 & 0.03 \\
$\mathrm{Mg}$ & 3.51 & 0.89 & 0.25 \\
$\mathrm{Na}$ & 0.25 & 0.53 & 2.12 \\
$\mathrm{~K}$ & 0.66 & 1.39 & 2.11 \\
\hline
\end{tabular}

${ }^{*}$ Recalculated to 100 per cent from oxides (number of samples of rock and soil $=5$ ).

removal of major elements in solution and fixation of $\mathrm{Al}$ in clay minerals and $\mathrm{Fe}$ in goethite. The soilto-rock ratio is high for $\mathrm{Al}$ and $\mathrm{Fe}$ but much lower for $\mathrm{Ca}$ and $\mathrm{Mg}$. Comparison of limestone bedrock and local soil composition (table 4) indicates that the relative mobility of elements during weathering has been $\mathrm{Ca}>\mathrm{Mg}>\mathrm{Na}>\mathrm{K}>\mathrm{Si}>\mathrm{Al}>\mathrm{Fe}$.

\section{Effects of chemical weathering on river water quality}

Chemical weathering of rocks is an interaction between rock and water under the conditions prevailing on the earth's surface. In order to examine the influence of weathering on water composition, a five-year water quality database was acquired from Central Water Commission (CWC). It has 13 sampling stations distributed all over the basin. The monthly water analysis data averaged over a five-year period (1991-95) is listed in table 5. The charge balance of total cations $\mathrm{TZ}^{+}$and anions $\mathrm{TZ}^{-}$on equivalent basis can be represented by a linear regression equation:

$$
\mathrm{TZ}^{-}\left(\mu \mathrm{eqL} L^{-1}\right)=1.11 \mathrm{TZ}^{+}\left(\mu \mathrm{eqL} L^{-1}\right)-258.75 \text {. }
$$

As the maximum discrepancy in cation-anion balance was $8.4 \%$, this database is considered suitable for further interpretation. Reconfirmation of the water composition at CWC sampling stations were carried out for major ions by standard analytical methods mentioned in table 6 . The results of the major ion analysis for these water samples agree well with the concentration ranges reported earlier by the CWC.

The TDS concentration is in the range of 76 to $343 \mathrm{mgL}^{-1}$ with a mean of $155 \mathrm{mgL}^{-1}$. Bicarbonate is the dominant ion followed by calcium, sulphate, silica, sodium and magnesium (table 5). The linear regression analysis of dissolved 
Table 5. Average water composition of the Mahanadi river at different stations.

\begin{tabular}{lccrcrrrrr}
\hline \multicolumn{1}{c}{ Station } & $\mathrm{pH}$ & $\mathrm{SiO}_{2}$ & \multicolumn{1}{c}{$\mathrm{Na}$} & $\mathrm{K}$ & $\mathrm{Ca}$ & $\mathrm{Mg}$ & $\mathrm{HCO}_{3}$ & $\mathrm{Cl}$ & $\mathrm{SO}_{4}$ \\
\hline 1. Baronda & 7.23 & 14.03 & 4.83 & 2.05 & 12.68 & 2.88 & 51.3 & 9.71 & 10.04 \\
2. Rajim & 7.21 & 14.28 & 7.07 & 1.93 & 18.34 & 3.79 & 74.0 & 10.05 & 6.98 \\
3. Simga & 7.75 & 14.12 & 19.58 & 5.01 & 31.07 & 10.41 & 141.7 & 15.19 & 21.11 \\
4. Andhiyarkore & 7.76 & 19.16 & 43.61 & 4.14 & 39.56 & 17.82 & 222.2 & 15.28 & 57.45 \\
5. Jondhra & 7.77 & 16.40 & 22.76 & 3.89 & 30.85 & 12.51 & 143.6 & 16.55 & 32.34 \\
6. Rampur & 7.58 & 13.20 & 14.62 & 1.88 & 26.60 & 6.64 & 114.2 & 11.85 & 10.35 \\
7. Bamnidih & 7.35 & 14.75 & 11.17 & 3.03 & 17.64 & 4.53 & 73.0 & 11.4 & 20.52 \\
8. Basantpur & 7.73 & 16.55 & 15.49 & 3.13 & 23.50 & 7.73 & 110.2 & 12.83 & 18.95 \\
9. Kurubhata & 7.33 & 17.24 & 5.71 & 2.22 & 11.49 & 3.77 & 55.3 & 8.37 & 15.36 \\
10. Sundergarh & 7.39 & 15.91 & 9.76 & 1.48 & 13.64 & 4.02 & 67.7 & 8.70 & 13.28 \\
11. Salebhata & 7.83 & 14.65 & 22.32 & 1.76 & 26.39 & 7.90 & 137.5 & 11.86 & 9.00 \\
12. Kantamal & 7.64 & 18.19 & 14.80 & 2.19 & 20.66 & 6.29 & 102.2 & 10.85 & 10.42 \\
13. Tikarpara & 7.47 & 14.48 & 7.87 & 1.73 & 20.18 & 4.91 & 87.5 & 10.80 & 9.83 \\
\hline
\end{tabular}

Note: All parameters except $\mathrm{pH}$ are in $\mathrm{mgL}^{-1}$.

Table 6. Analytical parameters used for characterizing the water samples of various stations.

\begin{tabular}{llcc}
\hline Parameter & Method of analysis & Std. dev. (\%) & $\begin{array}{r}\text { Relative } \\
\text { error (\%) }\end{array}$ \\
\hline pH & pH meter in field & 5.8 & 1.2 \\
Conductivity & Conductivity meter at site & 8.0 & 2.1 \\
Bicarbonate & Acid (HCl) titration at site $_{\text {Chloride }}^{\mathrm{AgNO}_{3} \text { titration }}$ & 15.5 & 2.3 \\
Sulphate & $\mathrm{BaCl}_{2}$ titration & 4.2 & 1.7 \\
$\mathrm{Na}$ and K & $\mathrm{Flame} \mathrm{AAS}_{\mathrm{Ca} \text { and } \mathrm{Mg}}$ & 9.1 & 1.2 \\
Dissolved Si & Molybdo-silicate method by & 17.3 & 4.0 \\
& spectrophotometer & 9.2 & 1.9 \\
& & & 4.2 \\
\hline
\end{tabular}

Table 7. Correlation coefficient matrix (confidence level: 95\%).

\begin{tabular}{|c|c|c|c|c|c|c|c|c|c|c|c|}
\hline & $\mathrm{pH}$ & E.C. & TDS & $\mathrm{SiO}_{2}$ & $\mathrm{Na}$ & K & $\mathrm{Ca}$ & $\mathrm{Mg}$ & $\mathrm{HCO}_{3}$ & $\mathrm{Cl}$ & $\mathrm{SO}_{4}$ \\
\hline $\mathrm{pH}$ & 1.00 & 0.76 & 0.74 & 0.34 & 0.76 & 0.53 & 0.82 & 0.77 & 0.82 & 0.77 & 0.46 \\
\hline E.C. & & 1.00 & 0.99 & 0.50 & 0.98 & 0.70 & 0.96 & 0.99 & 0.99 & 0.85 & 0.87 \\
\hline TDS & & & 1.00 & 0.54 & 0.98 & 0.69 & 0.93 & 0.98 & 0.98 & 0.82 & 0.89 \\
\hline $\mathrm{SiO}_{2}$ & & & & 1.00 & 0.55 & 0.25 & 0.29 & 0.53 & 0.44 & 0.19 & 0.63 \\
\hline $\mathrm{Na}$ & & & & & 1.00 & 0.68 & 0.91 & 0.97 & 0.97 & 0.77 & 0.86 \\
\hline $\mathrm{K}$ & & & & & & 1.00 & 0.69 & 0.73 & 0.64 & 0.84 & 0.74 \\
\hline $\mathrm{Ca}$ & & & & & & & 1.00 & 0.94 & 0.97 & 0.91 & 0.76 \\
\hline $\mathrm{Mg}$ & & & & & & & & 1.00 & 0.97 & 0.87 & 0.89 \\
\hline $\mathrm{HCO}_{3}$ & & & & & & & & & 1.00 & 0.84 & 0.78 \\
\hline $\mathrm{Cl}$ & & & & & & & & & & 1.00 & 0.69 \\
\hline $\mathrm{SO}_{4}$ & & & & & & & & & & & 1.00 \\
\hline
\end{tabular}

components brings out possible ionic associations (table 7). A strong positive correlation $(r=0.99)$ exists between electrical conductivity and TDS as expected. A strong correlation $(r>0.9)$ exists among sodium, calcium, magnesium and bicarbonate ions, which indicates a common rock source for them.

Much of the weathering capability of natural water is due to the mild acidity produced by dissolved carbon dioxide. The partial pressure of $\mathrm{CO}_{2}$ at $25^{\circ} \mathrm{C}$ is calculated from $\mathrm{pH}$ and bicarbonate content of river water using the equation

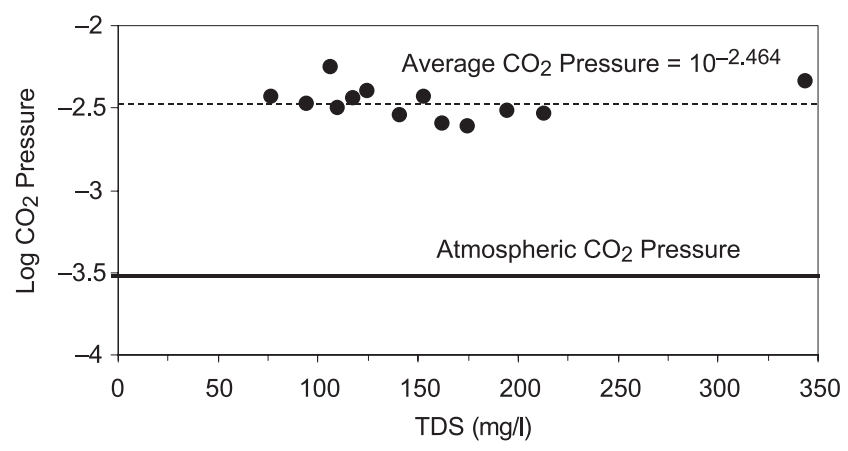

Figure 4. Variation of apparent $\mathrm{CO}_{2}$ pressure with TDS. 

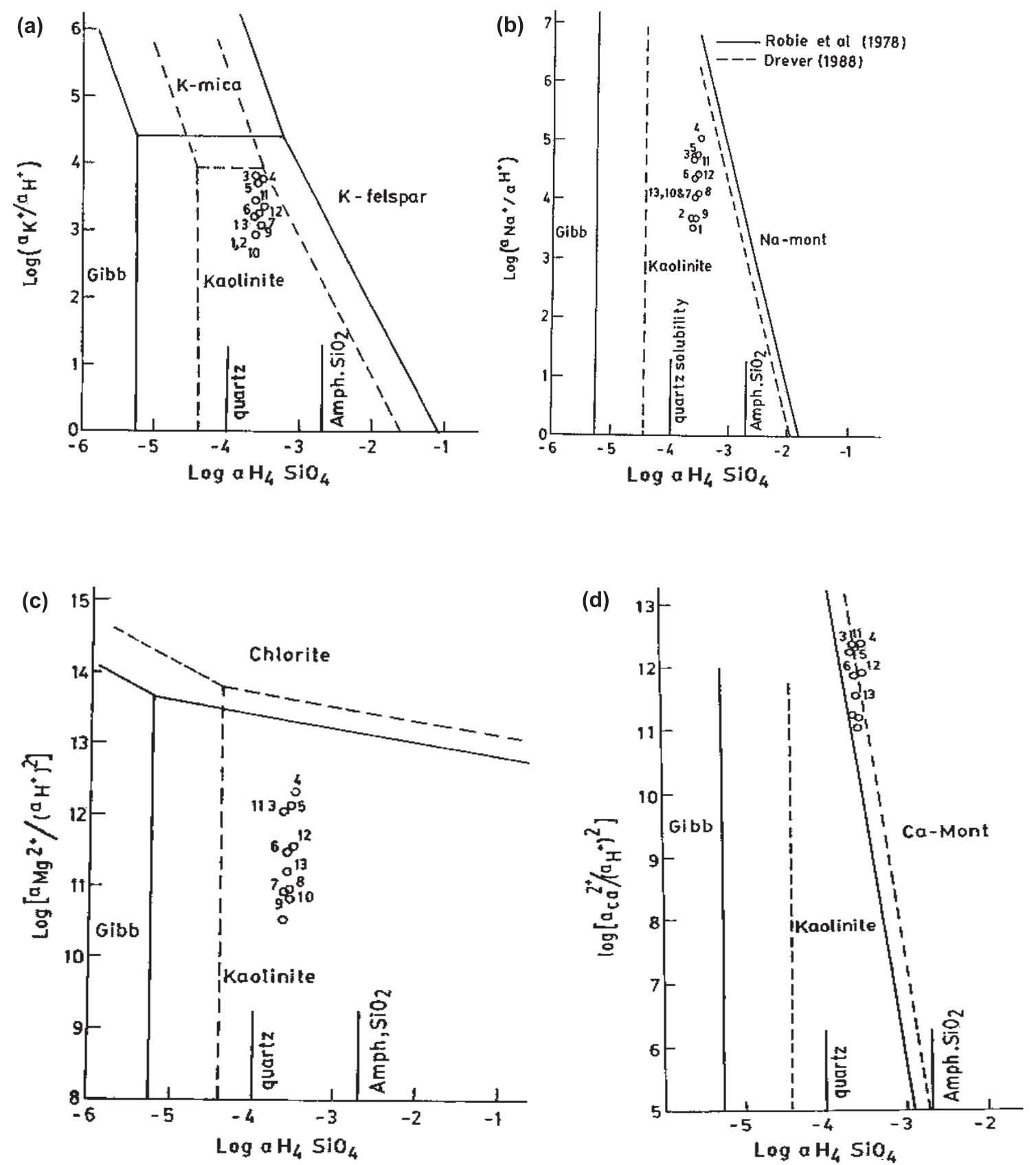

Figure 5. (a) Stability diagram for $\mathrm{K}_{2} \mathrm{O}-\mathrm{Al}_{2} \mathrm{O}_{3}-\mathrm{SiO}_{2}-\mathrm{H}_{2} \mathrm{O}$ system; (b) Stability diagram for $\mathrm{Na}_{2} \mathrm{O}-\mathrm{Al}_{2} \mathrm{O}_{3}-\mathrm{SiO}_{2}-\mathrm{H}_{2} \mathrm{O}$ system; (c) Stability diagram for $\mathrm{MgO}-\mathrm{Al}_{2} \mathrm{O}_{3}-\mathrm{SiO}_{2}-\mathrm{H}_{2} \mathrm{O}$ system; and (d) Stability diagram for $\mathrm{CaO}_{-}-\mathrm{Al}_{2} \mathrm{O}_{3}-\mathrm{SiO}_{2}-\mathrm{H}_{2} \mathrm{O}$ system.

$\log P_{\mathrm{CO}_{2}}=7.9+\log \mathrm{aH}_{2} \mathrm{CO}_{3}-\mathrm{pH}$. Comparison of river $P_{\mathrm{CO}_{2}}$ with that of the atmosphere indicates degree of disequilibrium at the interface. With an average $\log P_{\mathrm{CO}_{2}}=-2.464, \mathrm{CO}_{2}$ pressure in each of the tributaries and the main Mahanadi river is higher than the atmospheric $P_{\mathrm{CO}_{2}}=10^{-3.5}$ atm. (figure 4). Two probable possibilities to explain the observed disequilibrium may be that:

- a perennial river like Mahanadi contains a significant fraction of high $\mathrm{CO}_{2}$ contribution from groundwater and
- the rate of release of excess $\mathrm{CO}_{2}$ for attaining reequilibrium with the atmosphere is slower than the rate of solubility of $\mathrm{CO}_{2}$.

The $\mathrm{CO}_{2}$ pressure remains fairly constant all over the basin independent of dissolved load along the course of river (figure 4). However, samples from the upstream of the Mahanadi river basin where limestone and calcareous shales are dominant have relatively higher $P_{\mathrm{CO}_{2}}$ than the downstream water draining the non-carbonate rocks. 


\subsection{Carbonate and silicate mineral equilibria}

Weathering of carbonate and silicate minerals in limestone not only influences soil formation but also the water quality. Therefore, it is important to evaluate the state of saturation of river water in terms of solubility products of the two minerals, calcite and dolomite. The saturation index for calcite is between -1.58 and 0 and for that of dolomite is between -3.64 and 0 . This range of values in general suggests undersaturation of river water with respect to these two minerals. This undersaturation explains aggressive chemical weathering and development of solution features in the study area.

Silicate mineral equilibria for common clay minerals such as kaolinite, Na-montmorilonite and Ca-montmorilonite are evaluated in terms of thermodynamic data of Robie et al (1978) and Drever (1988). Cation $/ \mathrm{H}^{+}$ion activity ratios and silica activity at different sampling stations plot within the kaolinite field in the stability diagrams for $\mathrm{K}_{2} \mathrm{O}, \mathrm{Na}_{2} \mathrm{O}$ and $\mathrm{MgO}-\mathrm{Al}_{2} \mathrm{O}_{3}-\mathrm{SiO}_{2}-\mathrm{H}_{2} \mathrm{O}$ systems (figure 5a, b and c). On the other hand, the analysed data fall across the kaolinite/Ca-smectite boundary in the stability diagram for $\mathrm{CaO}-\mathrm{Al}_{2} \mathrm{O}_{3}-$ $\mathrm{SiO}_{2}-\mathrm{H}_{2} \mathrm{O}$ systems (figure $5 \mathrm{~d}$ ). These suggest that kaolinite and $\mathrm{Ca}$-smectite are stable in the river environment. This theoretical observation is supported by the presence of kaolinite and a glycolexpansive smectite in river suspended sediment and soils.

\subsection{Carbonate vs. silicate weathering}

In the entire Mahanadi river, the $\mathrm{Ca}+\mathrm{Mg}$ concentration is balanced by the $\mathrm{HCO}_{3}$ on an equivalent basis (figure 6), suggesting that the carbonate weathering is more important than the silicate weathering in controlling the Mahanadi water quality. Further, it is evident from the ternary diagram (figure 7) that the Mahanadi river waters plot near the carbonate end. This affinity towards the carbonate end suggests that the dissolved components derived from limestone weathering in the upper part of the basin overwhelm the silicate weathering products in the downstream segments even outside the limestone terrain. This conclusion supports the previous observations of Chakrapani and Subramanian (1990).

R-mode factor analysis of the normalized monthly water composition data suggests that more than $90 \%$ of the data could be explained by three factors (table 8). The factor matrix thus obtained was subjected to oblimin rotation with Kaiser normalization. The factor matrix

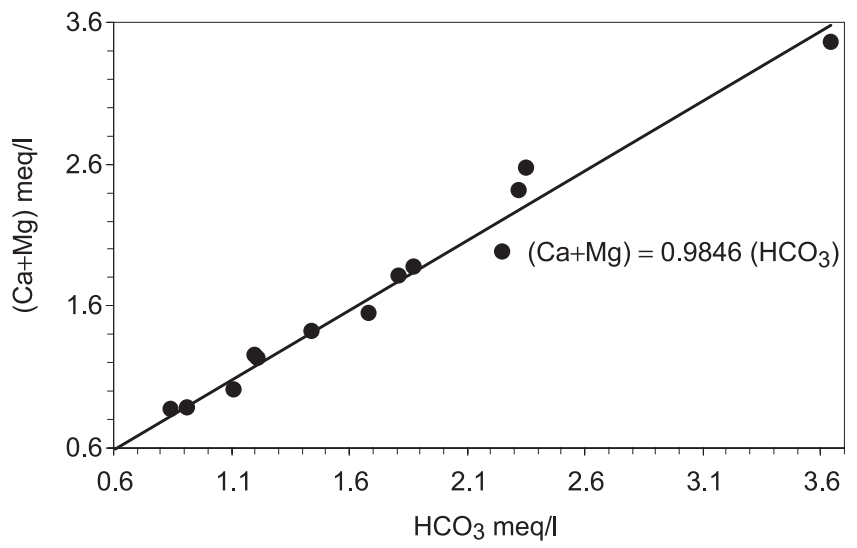

Figure 6. Balance of $(\mathrm{Ca}+\mathrm{Mg})$ and $\mathrm{HCO}_{3}$.

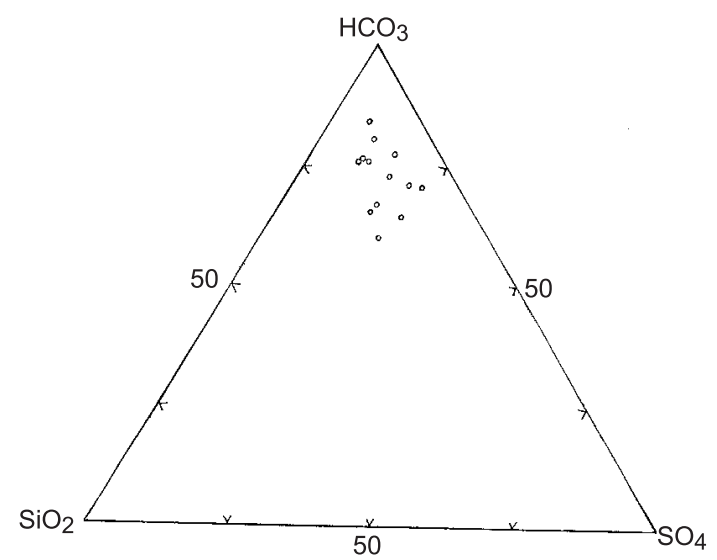

Figure 7. Ternary plot of bicarbonate, silica and sulphate.

(table 8) shows that $70 \%$ of total variance is explained by factor-1 consisting of $\mathrm{Na}-\mathrm{Ca}-\mathrm{Mg}-$ $\mathrm{HCO}_{3}$ assemblage. This dominant factor comprising strong loadings by $\mathrm{Ca}, \mathrm{Mg}$ and $\mathrm{HCO}_{3}$ can be explained by the dominance of carbonate weathering in the basin. On the other hand, association of $\mathrm{Na}$ with factor-1 may be related to the leaching of silicate clay impurities in limestone. Factor-2 explains more than $12 \%$ of the total variance and is characterized by a high factor-score for silica. This factor may be interpreted as due to weathering of silicates. Factor-3 accounts for $7 \%$ of total variance with significant loadings for $\mathrm{K}$ and $\mathrm{Cl}$. Although evaporite weathering contributing $\mathrm{K}$ and $\mathrm{Cl}$ to the observed dissolved load of Mahanadi is indicated, available geological information is insufficient to confirm that possibility. The significant factors observed in the present dataset are also evident in the correlation matrix, thus confirming the dominance of carbonate weathering in controlling the dissolved load of Mahanadi. 
Table 8. Oblimin rotated $R$-mode factor matrix of chemical data $(n=65)$.

\begin{tabular}{lcccc}
\hline Variable & Factor-1 & Factor-2 & Factor-3 & Communality \\
\hline $\mathrm{SiO}_{2}$ & 0.160 & $\mathbf{0 . 9 9 6}$ & 0.149 & 0.993 \\
$\mathrm{Na}$ & 0.968 & 0.120 & 0.629 & 0.945 \\
$\mathrm{~K}$ & 0.651 & 0.178 & $\mathbf{0 . 9 4 6}$ & 0.900 \\
$\mathrm{Ca}$ & $\mathbf{0 . 9 3 8}$ & 0.133 & 0.768 & 0.901 \\
$\mathrm{Mg}$ & $\mathbf{0 . 9 6 7}$ & 0.221 & 0.745 & 0.949 \\
$\mathrm{HCO}_{3}$ & $\mathbf{0 . 9 7 1}$ & 0.191 & 0.679 & 0.946 \\
$\mathrm{Cl}^{\mathrm{SO}_{4}}$ & 0.744 & 0.042 & $\mathbf{0 . 9 0 9}$ & 0.852 \\
Eigen value (principal & 0.837 & 0.241 & 0.624 & 0.710 \\
$\quad$ component solution) & 5.616 & 0.986 & 0.594 & \\
Percentage variance explained & 70.20 & 12.30 & & \\
Cumulative percentage of & 70.20 & 82.50 & 89.90 & \\
$\quad$ variance & & & &
\end{tabular}

Note: An eigen value of 0.5 is assigned for extraction of factors. Size of eigen value represents the variance of the original data that has been extracted to each factor. The generally high communalities indicate that $90 \%$ of the variance is explained by 3 factors.

\section{Conclusions}

- Congruent dissolution of the stromatolitic limestone by Mahanadi river water has resulted in typical karst features. At the same time, the incongruent weathering of glauconite has given rise to red and black soil profiles over the limestone bedrock. Thus, a simultaneous congruent/incongruent weathering is the characteristic of the Mahanadi basin.

- The river water is undersaturated with respect to calcite and dolomite resulting in aggressive chemical weathering of limestone.

- The clay minerals kaolinite and Ca-smectite are thermodynamically stable in the Mahanadi river water and hence may be insignificant contributors of silicate weathering products to the Mahanadi water.

- Carbonate weathering in the basin is a primary factor influencing the quality of Mahanadi water.

\section{Acknowledgements}

Authors are grateful to the Central Water Commission authorities for permission to use their data. We sincerely acknowledge the valuable suggestions from reviewers, which helped to improve the original manuscript. Help during the field visits from Envirotech Pvt. Ltd., New Delhi is also acknowledged. This work is a part of Ph.D dissertation of BKP.

\section{References}

Berner E K and Berner R A 1987 The Global Water Cycle: Geochemistry and Environment; Prentice Hall, Englewood Cliffs, N.J., p. 397.
Burst J E 1958 Mineral heterogeneity in glauconite pellets; American Mineralogist. 43 481-497.

Chakrapani G J and Subramanian V 1990 Preliminary studies on the geochemistry of the Mahanadi river basin, India; Chem. Geol. 81 241-253.

Drever J I 1988 The Geochemistry of Natural Waters, 2nd edn, Prentice Hall, Englewood Cliffs, N.J., p. 437.

Drever J I 1997 Catchment mass balance, In: Geochemical processes, weathering and groundwater recharge in catchments; (eds) O M Saether and P de Caritat, Balkema, pp. 241-261.

Das N, Das M and Mishra V P 1989 Geology of BemetraKodwa-Bera Area, Durga District, Madhya Pradesh; Rec. Geol. Surv. Ind. 122(6) 16-17.

Das N, Das M G and Arora Y K 1990 Microfacies assemblage of gypsum from Chattisgarh basin - A Sabkha model of evaporite formation; Geol. Surv. India, Spl. Publ. 28 639-647.

Garrels R M and Christ C L 1965 Solutions, Minerals and Equilibria; (New York: Harper and Row), 450 pp.

Gibbs R J 1970 Mechanisms controlling world water chemistry; Science $\mathbf{1 7 0} 1088$.

Kale V S 1991 Constraints on the evolution of the Purana basins of Peninsular India; J. Geol. Soc. India 38 231-252.

Meybeck M 1987 Global chemical weathering of surficial rocks estimated from river dissolved load; $\mathrm{Am}$. J. Sci. 287 401-428.

Murti K S 1987 Stratigraphy and sedimentation in Chattishgarh basin; Proc. Purana Basins of India, Memoir 6, Geol. Soc. India, pp. 239-260.

Mukherjee A 1990 Phosphogenesis in Pre-Cambrian rocks of Durga district, Madhya Pradesh; unpublished Ph.D. thesis, Ravi Shankar University, Raipur, p. 246.

Naidu A S, Mowatt T C, Somayajulu B L K and Rao K S 1985 Characteristics of clay minerals in the bed loads of major rivers in India; $S C O P E / U N E P$, Hamburg, pp. 559-569.

Ohrui K and Mitchell M J 1998 Stream water chemistry in Japanese watersheds and its variability on a small regional scale, Water Resour. Res. 34 15531561.

Panigrahy B K 1991 Geochemistry of Rock weathering in upper part of Mahanadi Basin, Unpublished Ph.D thesis submitted to IIT, Kanpur. 
Rao K L 1979 Indian water wealth: Its assessment, uses and projections; Orient Longman, pp. 261.

Ray S B, Mohanti M and Somayajulu B L K 1984 Suspended matter, major cations and dissolved silicon in the estuarine waters of the Mahanadi river, India; J. Hydrol. 69 183-196.

Raymahashay B C 1986 Geochemistry of bicarbonate in river water; J. Geol. Soc. India 27 114-118.

Robie R A, Hemingway B S and Fisher J R 1978 Thermodynamic properties of minerals and related substances at 298.15 K and 1 Bar ( $10^{5}$ Pascals $)$ pressure and at higher temperatures; U.S. Geol. Surv. Bull. 1452456.
Stallard R F and Edmond L M 1983 Geochemistry of the Amazon, 2: The influence of geology and weathering environment on the dissolved load; J. Geophys. Res. 88 9671-9688.

Subramanian V 1987 Environmental Geochemistry of Indian River basins - A review; J. Geol. Soc. India 29 205-220.

Tardy Y and Garrels R M 1974 A method for estimating the Gibbs energy of formation of layer silicates; Geochim. Cosmochim. Acta 38 1101-1116.

Wolf R G 1967 X-ray and chemical study of weathering of glauconite; American Mineralogist. 52 1129-1138. 